\title{
Mental Health of College Students and Its Relation to Life Satisfaction and Social Media Abuse
}

\author{
Muhammad Defrianto, 1 \\ Alfiasari $^{2}$ \\ ${ }^{1,2}$ Faculty of Human Ecology, Institut \\ Pertanian Bogor, Bogor-Indonesia \\ Corresponding Author: Alfiasari, email: \\ alfiasari@apps.ipb.ac.id; Jl. Kamper, \\ Babakan, Dramaga, Bogor, 16680
}

\begin{abstract}
Adolescents are known for their critical development period due to problems they often face in their daily lives. The problem occurs as a result of adolescent developmental tasks that have not been appropriately fulfilled. One of the problems of adolescents is social media abuse. This study analyzes college students' mental health and their relation to life satisfaction and social media abuse. This research is a quantitative approach that involved 302 college students from the Vocational School of IPB University as respondents. The sampling technique used convenience sampling considering the data is taken online and distributed to as many population members as possible. With this technique, respondents are assumed to be willing to fill out the questionnaire because they feel more comfortable and safer. The results prove that male students in this study more often abuse social media than female students. College student life satisfaction in this study is not related and does not influence mental health and social media abuse. Mental health is proven to be related and influenced by abuse behavior, where an increase in mental health will decrease the tendency of social media abuse on college students.
\end{abstract}

Keywords: college students; life satisfaction; mental health; social media abuse

\begin{abstract}
Abstrak: Remaja dikenal dengan masa perkembangannya yang kritis dikarenakan masalah yang sering mereka hadapi di kehidupan sehari-hari. Masalah tersebut hadir sebagai dampak dari tugas perkembangan remaja yang belum dapat terpenuhi sepenuhnya. Salah satu masalah remaja adalah penyalahgunaan media sosial. Penelitian ini bertujuan untuk menganalisis kesehatan mental mahasiswa dan hubungannya dengan kepuasan hidup dan penyalahgunaan media sosial. Penelitian ini merupakan penelitian dengan pendekatan kuantitatif yang melibatkan 302 mahasiswa dari Sekolah Vokasi Institut Pertanian Bogor sebagai responden. Teknik pengambilan contoh menggunakan convenience sampling mengingat data diambil secara online dan disebar kepada sebanyak mungkin anggota populasi sehingga dengan teknik ini responden diasumsikan bersedia mengisi kuesioner karena merasa lebih nyaman dan aman. Hasil membuktikan mahasiswa laki-laki dalam penelitian ini lebih sering menyalahgunakan media sosial ketimbang mahasiswa perempuan. Kepuasan hidup mahasiswa dalam penelitian ini tidak berhubungan dan tidak berpengaruh terhadap kesehat-
\end{abstract}


an mental dan penyalahgunaan media sosial. Kesehatan mental terbukti berhubungan dan berpengaruh dengan perilaku penyalahgunaan dimana peningkatan kesehatan mental akan menyebabkan penurunan kecenderungan penyalahgunaan media sosial pada mahasiswa dalam penelitian ini.

Kata Kunci: kepuasan hidup; mahasiswa; kesehatan mental; penyalahgunaan media sosial

\section{A. Introduction}

Mental health currently becomes a serious issue to be discussed. Individuals with good mental health describe a person who has the values of goodness, truth, and godliness. ${ }^{1}$ Based on the 2018 Indonesia Basic Health Research, as many as 9.8 percent or around 26 million Indonesian population aged over 15 years experienced emotional, mental disorders. Without proper mental health, people will have difficulty living their daily lives. ${ }^{2}$ Heerdjan menyatakan, Mental health defined as a condition and state of mentalemotional. ${ }^{3}$ When talking about mental health in adolescents, the internet, especially social media, is one of the things that is allegedly a determining factor in adolescent mental health, considering that adolescents spend a lot of time accessing the internet and social media. Social media has been shown to have some potential negative effects on mental health such as anxiety and depression disorders, sleep disorders, body image issues, and fear of missing out ${ }^{4}$. When concerning social media that was previously proven to affect one's mental health, one of the questions that arise is how individuals with low mental health use social media.

Today, the internet has become one of the main features that people always need in gadgets using. However, technology and the internet just like a double-edged knife that can be useful if used properly but can have a negative impact if misused. ${ }^{5}$ One form of internet abuse that often occurs is social media

\footnotetext{
${ }^{1}$ Siswanto Siswanto, Kesehatan Mental: Konsep, Cakupan, dan Perkembangannya (Yogyakarta: Andi Offset, 2007).

2World Health Organization, “Investing in Mental Health," 2003, 52.

${ }^{3}$ Dede Rahmat Hidayat, Bimbingan Konseling: Kesehatan Mental di Sekolah (Bandung: Remaja Rosdakarya, 2013).

4Jonathan Glazzard and Samuel Stones, "Social Media and Young People's Mental Health," in Technology and Child Mental Health (IntechOpen, 209AD), 32, https://doi.org/10.5772/ intechopen.88569.

${ }^{5}$ Ridwan Sanjaya, Menyiasati Tren Digital pada Anak dan Remaja Oakarta: Elex Media Komputindo, 2011).
} 
abuse. Social media has been defined as a form of electronic communication (such as websites for social networking and microblogging) where users create online communities to share information, ideas, personal messages, or other content. ${ }^{6}$ Unfortunately, social media with all its sophistication has a high risk of misuse. Fisher said that the misuse of cellular technology and social media networks had become a common thing in many countries. The effort to overcome this abuse might require a long amount of time and requires a lot of effort. $^{7}$

Fairly free use certainly encourages users to use social media not only positively but also negatively. Social media is also often misused for negative things such as the dissemination of immoral content, false news or hoaxes, and expressions of hatred or hate speech. ${ }^{8} \mathrm{~A}$ total of 215 male and 92 female students from 10,713 undergraduate students at one of the Nigerian universities involved in the research of Chukwudi and Taiwo ${ }^{9}$ were found to use social media negatively by viewing and distributing pornographic content (47.8\%), cyberbullying or harassing and insulting others (42.9\%), and creating fake accounts (13\%). ${ }^{10}$ Pandie and Weisman concluded that the perpetrators of social media abuse in the form of cyberbullying are influenced by family, environmental, and self-factors. Therefore, mental health as part of the selffactor, is then expected to have an influence on the abuse of social media. The vulnerable soul in youth due to low mental health can be a factor in youth

6Emily Frith, "Social Media and Children's Mental Health: A Review of the Evidence," The Education Policy Institute, 2017, 1-29.

${ }^{7}$ Eddie John Fisher, "From Cyber Bullying to Cyber Coping: The Misuse of Mobile Technology and Social Media and Their Effects on People's Lives," Business and Economic Research 3, no. 2 (2013): 127-45, https://doi.org/10.5296/ber.v3i2.4176.

${ }^{8}$ Siti Zulaiha, Sagiman Sagiman, and Mutia Mutia, "Edukasi Literasi Informasi bagi Anak dan Remaja untuk Meminimalisir Penyalahgunaan Media Jejaring Sosial," Jurnal Harkat: Media Komunikasi Gender 15, no. 2 (November 27, 2019): 116-25, https://doi.org/10.15408/harkat. v15i2.13469.

9 John Henry Chukwudi and Egbeyemi Taiwo, "Use and Abuse of Social Networking Websites (Facebook) among Undergraduate Students in Tai Solarin University of Education," in Proceedings of the 2nd Interdisciplinary Conference of TASUED-UCC 2016, Tai Solarin University of Education, Nigeria, 2016.

${ }^{10}$ Mira Marleni Pandie and Ivan Th. J. Weismann, "Pengaruh Cyberbullying di Media Sosial terhadap Perilaku Reaktif sebagai Pelaku maupun sebagai Korban Cyberbullying pada Siswa Kristen SMP Nasional Makassar," Jurnal Jaffray 14, no. 1 (2016): 43-62, https://doi.org/10.25278/ jj.v14i1.188.43-62. 
becoming a cyberbullying agent. ${ }^{11}$ In other words, the perpetrators of social media abuse are expected to have low mental health.

Some previous research has found that mental health and social media abuse also correlated with life satisfaction. Nalini Maria West ${ }^{12}$ by referring to the concept of life satisfaction according to Lounsbury et al., explained that life satisfaction in general measures individual satisfaction towards oneself, leisure, pleasure, health, social life, academic, career, and life as a whole. If one's life satisfaction is low, it can be said that someone is experiencing problems or obstacles in certain aspects of life. ${ }^{13}$ Life satisfaction has been proven to affect one of the negative impacts of social media, namely dependence. ${ }^{14} \mathrm{Li}$ et al., found that satisfaction with one's psychological needs also influenced a mediator between depressing living conditions and excessive use of social media. The use of social media that is not normal and not appropriate is what can then cause dependency. Individuals who use social media so intensely as to become addicted tend to have a higher potential in abusing social media. ${ }^{15}$ Social needs in the real world that are not appropriately met encourage social media use as an alternative. The loneliness that can occur due to unmet social needs also affects social media use that is not appropriate or has a negative impact. ${ }^{16}$ Therefore, low life satisfaction is suspected to be the cause of individuals using social media and can be assumed to contribute to the abuse of social media indirectly.

${ }^{11}$ El Chris Natalia, "Remaja, Media Sosial dan Cyberbullying," Jurnal Ilmiah Komunikasi 5, no. 2 (2016): 119-37, https://doi.org/10.33508/jk.v5i2.991.

${ }^{12}$ Nalini Maria West, "The Relationship among Personality Traits, Character Strengths, and Life Satisfaction in College Students," Dissertation Abstracts International: Section B: The Sciences and Engineering 67, no. 10-B (2007): 6107.

13John W. Lounsbury et al., "An Investigation of Broad and Narrow Personality Traits in Relation to General and Domain-Specific Life Satisfaction of College Students," Research in Higher Education 46, no. 6 (2005): 707-29, https://doi.org/10.1007/s11162-004-4140-6.

14 Phil Longstreet and Stoney Brooks, "Life Satisfaction: A Key to Managing Internet \& Social Media Addiction," Technology in Society 50 (2017): 73-77, https://doi.org/10.1016/j.techsoc. 2017.05.003.

${ }^{15}$ Dongping Li et al., "Stressful Life Events and Adolescent Internet Addiction: The Mediating Role of Psychological Needs Satisfaction and the Moderating Role of Coping Style," Computers in Human Behavior 63 (2016): 408-15, https://doi.org/10.1016/j.chb.2016.05.070.

16Riska Dwi Cahyani Wahyu Agusti and Tino Leonardi, "Hubungan antara Kesepian dengan Problematic Internet Use pada Mahasiswa," Jurnal Psikologi Klinis dan Kesehatan Mental 4, no. 1 (2015): 9-13. 
Life satisfaction and mental health are confirmed to be related to one another. Previous research has argued that positive mental health is derived mainly from the perspective of life satisfaction, where a low level of life satisfaction is significantly associated with mental health problems or having low mental health. ${ }^{17}$ Individuals with low life satisfaction by definition, according to Nayana mean having a reflective and low self-assessment and some things do not happen or do not work well on the individual. ${ }^{18}$ Oppositely, life satisfaction and quality of life are embodiments of mental health. ${ }^{19}$ The results of research also showed that poor mental health is highly related to the low satisfaction of one's life. ${ }^{20}$ Based on the explanation above, users who abuse social media by carrying out negative impact actions tend to be suspected of living with low life satisfaction and also having low mental health. Many types of research have been done relating to life satisfaction, mental health, or social media use. However, it is still very rare to find research that explains the relationship between life satisfaction, mental health, and social media abuse. Therefore, this research was conducted to analyze the relationship between college students' mental health, life satisfaction, and social media abuse. The results of research conducted by the media company "We Are Social" in a report titled "Digital in Indonesia 2019" explained that there were 33 percent of social was users aged 18-24 years and 33 percent of social media users aged 25-34 years. In other words, one of the most active social media users in Indonesia is adolescent. These facts encouraged this study to analyze college students' mental health and its relation to life satisfaction and social media abuse.

This study specifically aims to: 1 ) identify college student characteristics, life satisfaction, mental health, and social media abuse among college students,

\footnotetext{
${ }^{17}$ Margaret Grigg and Shekhar Saxena, "Promoting Mental Health Nursing Research in Low and Middle Income Countries," International Nursing Review 51, no. 4 (2004): 194-95, https://doi.org/10.1111/j.1466-7657.2004.00268.x.

${ }^{18}$ Firra Noor Nayana, "Kefungsian Keluarga dan Subjective Well-Being pada Remaja," Jurnal Ilmiah Psikologi Terapan 1, no. 230-244 (2013), https://doi.org/10.22219/jiptv1i2.1580.

${ }^{19} \mathrm{M}$. Hadjam and Wahyu Widhiarso, "Pengujian Model Peranan Kecakapan Hidup terhadap Kesehatan Mental," Jurnal Psikologi UGM 38, no. 1 (2011): 61-72, https://doi.org/10.22146/ jpsi.7665.

${ }^{20}$ Thomas Puvill et al., "Impact of Physical and Mental Health on Life Satisfaction in Old Age: A Population Based Observational Study," BMC Geriatrics 16, no. 1 (2016): 1-9, https://doi.org/ 10.1186/s12877-016-0365-4.
} 
2) analyze the relationship between college student characteristics, life satisfaction, mental health with social media abuse, and 3) analyzing the influence of college student characteristics, life satisfaction, and mental health on social media. This research is expected to be a resource for families, governments, and communities regarding the relationship and influence of life satisfaction and mental health on college students' social media abuse.

\section{B. Method}

This research is quantitative research conducted by an online survey at the Vocational School of IPB University students. Data collection in this study was conducted from February to March 2020. The population in this study were all students of the Vocational School of IPB University from the first year until the third year totaling 6,923 students. The first year consisted of 2,308 students, the second year was 2,383 students, and the third year was 2,232 students. The sampling technique used convenience sampling considering the data was taken by online survey since by this technique respondents were assumed to have a willingness to fill out the questionnaire because they might felt more comfortable and safe. Data collection started with distributing the online questionnaire from February to March 2020 to the entire study population. The sample of this research is all students in the population who filled out online questionnaires in that period. The number of students who filled out the online questionnaire was 302 people with the proportion of firstyear students was 24 percent, second-year students were 28.1 percent, and third-year students in 2019 was 47.6 percent. The data used in this study are primary data that are individual characteristics (age, gender, last education, and the number of social media users), reasons for using social media, life satisfaction, mental health, and social media abuse.

Life satisfaction is measured using the Quality of Life Scale instrument modified by West consisting of 11 statements that identify respondents' life satisfaction with themselves, life as a whole, friends, social environment, academics, and career. The instrument with a Cronbach's alpha value of 0.796 used a seven-point Likert scale answer that is very dissatisfied (score 1), dissatisfied (score 2), slightly dissatisfied (score 3), neutral (score 4), slightly satisfied (score 5), satisfied (score 6), and very satisfied (score 7). ${ }^{21}$

\footnotetext{
${ }^{21}$ Nalini Maria West, "The Relationship Among Personality Traits, Character Strengths, and Life Satisfaction in College Students" (University of Tennessee, Knoxville, 2006).
} 
Mental health is measured using the 12-Item General Health Questionnaire (GHQ-12) instrument by Goldberg and Williams.22 The instrument with a Cronbach's alpha value of 0.817 measures a person's mental health problems, which are described in the conditions and behavior experienced in the past few weeks. The instrument which amounts to 12 statements consists of 6 statements that are positive and six statements that are negative. The measurement scale used is a 4-point Likert scale with ratings never (score 1), rarely (score 2), often (score 3), and always (score 4) for statements that are positive and have the opposite value for negative statements. The minimum total score is 12 and the maximum is 48 with the condition that the higher the score of the respondent, the higher the level of mental health.

This research develops its own instrument by referring to the instrument created by Chukwudi and Taiwo. ${ }^{23}$ The instrument with a Cronbach's alpha value of 0.636 identifies the type of social media users based on Nasrullah ${ }^{24}$ and reason of respondents using social media that are used currently, the frequency of respondents in abusing social media, the behavior of social media abuse, and also the reasons of respondents in abusing social media.

Data processing consists of several stages, namely editing, coding, entering, cleaning, analyzing, and interpretation. Data analysis using Microsoft Excel and Statistical Product and Service Solutions. Data analyzes used in this study were descriptive analysis, chi-square test, Pearson correlation analysis, and logistic regression analysis. Descriptive analysis aims to identify the number, percentage, average value, minimum value, maximum value, and standard deviation of the college student characteristics, life satisfaction, mental health, and social media abuse variable. Chi-square test and Pearson correlation analysis aim to analyze the relationship between college student characteristics, life satisfaction, mental health, and social media abuse in college student. Logistic regression analysis aims to determine the influence of college student

${ }^{22}$ D. Goldberg and P. Williams, A User's Guide to the General Health Questionnaire (Windsor: NFER, 1998).

${ }^{23}$ Chukwudi and Taiwo, "Use and Abuse of Social Networking Websites (Facebook) among Undergraduate Students in Tai Solarin University of Education."

${ }^{24}$ Rulli Nasrullah, Media Sosial Perspektif Komunikasi, Budaya, dan Sosioteknologi (Bandung: Simbiosa Rekatama Media, 2015). 
characteristics, life satisfaction, and mental health on social media abuse in college students. In the logistic regression test, the index of social media abuse is categorized into two groups including the group "did not do social media abuse" labeled as " 0 " and the group "did social media abuse" labeled as " 1 ". The group of "did not do social media abuse" is students with zero social media abuse index while "did social media abuse" group is students with social media abuse index value more than zero.

\section{Results and Discussion}

The respondents totaling 302 students have a composition of 100 males (33.1\%) and 202 females (66.9\%). The age of respondents is in the age range of 17-23 years with an average age of 19 years old. The majority of students in this study had a general high school of education background (86.4\%) and the rest had an educational background in vocational high school (8.6\%) and Islamic school/Madrasah Aliyah (5\%).

Social media is divided into six types, namely social networking media, online journals (blogs), simple online journals (microblogs), media sharing, social bookmarks (social bookmarking) and shared content media (wikis) (Nasrullah, 2015). This study identified the number of social media used by respondents. Figure 1 presents the distribution of students based on the number of social media users and the results show that 42.4 percent of students claimed to only use one type of social media, the rest used more than one type of social media and interestingly, only one student used the six types of social media (0.3\%).

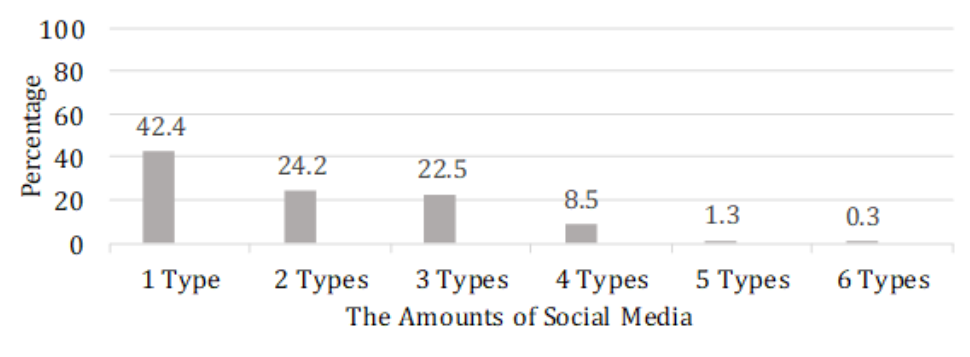

Figure 1.

Distribution of Respondents Based on Their Number of Social Media. 
The data of distribution of age and amounts of social media that used by respondents indicate that respondents aged 17-20 years use more types of social media compared to respondents aged 21-23 years. As many as 42.38 percents of college students claimed used only one type of social media, the rest used more than one type of social media and only one respondent used the six types of social media ( $0.3 \%)$. The most common types of social media that users are simple online journals (microblogs) and media sharing. An example of a simple online journal (microblog) is Twitter and examples of media sharing are YouTube, Instagram, and TikTok. These results are in accordance with the We Are Social survey (2019) which stated that YouTube and Instagram are types of social media that are widely used in Indonesia.

The life satisfaction of college students in this study had a minimum value of 25.76 and a maximum value of 92.42. The average value and standard deviation are 63.47 and 14.37, respectively. Life satisfaction identifies how satisfied students are with themselves, their overall life, friends, social environment, academics, and career. The highest proportion of college student life satisfaction in this study is in the less satisfied category (43\%). Figure 2 shows the distribution of respondents based on life satisfaction.

College students who are less satisfied with their lives are characterized by those at slightly dissatisfied levels until very dissatisfied levels with existing aspects of life. Table 1 also shows that 19.9 percent of college students felt slightly dissatisfied with satisfaction with their spare time. As many as 14.9 percent also felt slightly dissatisfied with their health and physical condition. Not a few others who only felt a little dissatisfied (16.9\%) of their friends.

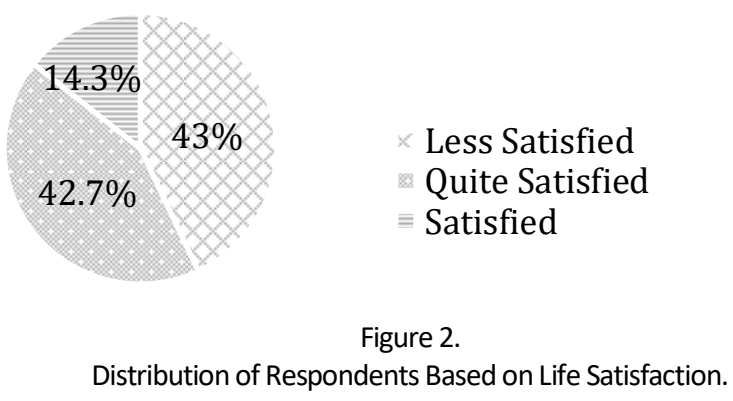


Muhammad Defrianto, Alfiasari

Table 1.

Distribution of Respondents Based on Life Satisfaction Indicator

\begin{tabular}{|c|c|c|c|c|c|c|c|c|}
\hline Indicator & VD & D & SD & $\mathrm{N}$ & SS & $S$ & VS & Total \\
\hline Self & 0.7 & 6.3 & 11.3 & 25.5 & 9.9 & 36.0 & 1.3 & 10.0 \\
\hline Happiness & 1.0 & 5.6 & 1.3 & 18.2 & 11.3 & 37.4 & 16.2 & 10.0 \\
\hline Spare time & 2.6 & 132 & 19.9 & 22.5 & 15.6 & 19.2 & 7.0 & 10.0 \\
\hline $\begin{array}{l}\text { Physical } \\
\text { health }\end{array}$ & 1.0 & 5.6 & 14.9 & 17.9 & 11.6 & 31.8 & 17.2 & 10.0 \\
\hline Friends & 1.0 & 3.3 & 16.9 & 26.8 & 13.6 & 27.5 & 1.9 & 10.0 \\
\hline Social life & 0.3 & 4.6 & 11.9 & 28.8 & 14.6 & 31.1 & 8.6 & 10.0 \\
\hline Major & 2.0 & 5.3 & 14.0 & 22.8 & 15.6 & 25.6 & 14.6 & 10.0 \\
\hline GPA & 4.0 & 8.9 & 13.6 & 1.9 & 21.2 & 3.5 & 1.9 & 10.0 \\
\hline $\begin{array}{l}\text { Interest } \\
\text { suitability }\end{array}$ & 1.7 & 4.6 & 14.6 & 26.8 & 17.9 & 24.2 & 1.3 & 10.0 \\
\hline $\begin{array}{l}\text { Career } \\
\text { suitability }\end{array}$ & 1.7 & 4.0 & 12.9 & 21.5 & 17.2 & 27.2 & 15.6 & 10.0 \\
\hline $\begin{array}{l}\text { Life as a } \\
\text { whole }\end{array}$ & 0.3 & 3.0 & 9.6 & 19.2 & 18.2 & 34.4 & 15.2 & 10.0 \\
\hline \multicolumn{3}{|c|}{ Note: VD = Very Dissatisfied } & SS & \multicolumn{3}{|c|}{ = Slightly Satisfied } & & \\
\hline $\mathrm{D}=$ & \multicolumn{2}{|c|}{ = Dissatisfied } & $\mathrm{s}$ & \multicolumn{3}{|c|}{ = Satisfied } & & \\
\hline SD & \multicolumn{2}{|c|}{ = Slightly Dissatisfied } & VS & \multirow{2}{*}{\multicolumn{3}{|c|}{$=$ Very Satisfied }} & & \\
\hline $\mathrm{N}$ & & & & & & & & \\
\hline
\end{tabular}

College students who are quite satisfied with their lives are characterized by those at a neutral level of satisfaction until slightly satisfied with existing aspects of life. This can be shown from Table 1 where 25.5 percent of students only feel neutral about themselves. Some students still feel neutral (26.8\%) towards friends and feel neutral (28.8\%) towards their social lives. Satisfaction with the suitability of college students' interests on the research results is also in the majority in the neutral category (22.8\%).

College students who are satisfied with their lives are characterized by those at the level of satisfaction that is satisfied to very satisfied with existing aspects of life. Table 1 shows that 36 percent of college students claimed to be satisfied with themselves. The results of the study presented in Table 1 show that most students also showed satisfaction (37.4\%) and were very satisfied (16.2\%) of their happiness. In addition, 31.8 percent of students said they were satisfied and 17.2 percent said they were very satisfied with their current health and physical condition. The majority of students were also satisfied with 
the current performance index (3.5\%), current interest suitability (24.2\%) and career suitability (27.2\%). For life as a whole, 34.4 percent of students said they were satisfied.

Based on the study results, respondents had a mental health index with a minimum value of 25 and a maximum of 10 . Standard deviations and mean values of mental health of college students were worth 13.29 and 65.31 respectively. This shows that college students' mental health is quite good but overall, not yet in the high mental health category. In this study, college students' mental health was measured by looking at the conditions and behavior experienced in the weeks before filling out the questionnaire. Figure 3 presents the distribution of respondents based on mental health and the results show that more than half of college students were at a medium level of mental health (56.3\%).

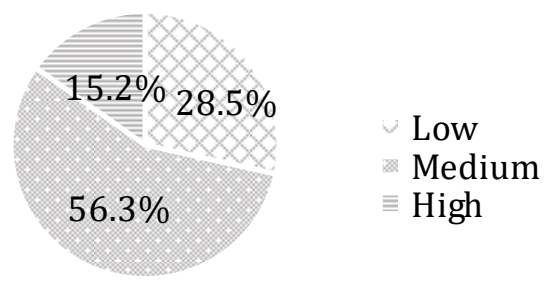

Figure 3.

Distribution of Respondents Based on Mental Health

College students with low mental health are characterized by those who still often experience mental-emotional obstacles in various aspects of life. Table 2 shows that 7.2 percent of students claimed that they could not overcome obstacles. Meanwhile, more than half of students still claimed that they often couldn't sleep because of anxiety (52\%) and often felt they were living under pressure (52.3\%). In fact, this study found that more than half of students often felt unhappy or depressed (61.3\%) and lost confidence (56.6\%).

College students with moderate mental health are characterized by those who often do not experience mental-emotional obstacles in various aspects of life. In Table 2, the results of the study show that more than half of the college students claimed that they could often face problems (59.3\%), often played an important role in a team (57.3\%) and often feel able to concentrate well (54.6\%). 
Muhammad Defrianto, Alfiasari

Table 2.

Distribution of Respondents Based on Mental Health Indicator

\begin{tabular}{lccccc}
\hline Indicator & Never & Rarely & Often & Always & Total \\
\hline Concentrate well & 0.0 & 4.1 & 54.6 & 5.3 & 10.0 \\
Can't sleep because of anxiety & 6.0 & 25.8 & 52.0 & 13.2 & 10.0 \\
Play an important role in a team & 2.0 & 24.8 & 57.3 & 15.9 & 10.0 \\
Able to make a decision & 0.0 & 16.9 & 49.7 & 33.4 & 10.0 \\
Living under pressure & 7.0 & 29.5 & 52.3 & 11.3 & 10.0 \\
Can't handle obstacles & 1.0 & 13.9 & 7.2 & 14.9 & 10.0 \\
Enjoy activities & 1.0 & 19.5 & 57.0 & 22.5 & 10.0 \\
Able to face problems & 0.3 & 13.9 & 59.3 & 26.5 & 10.0 \\
Not happy & 1.3 & 18.2 & 61.3 & 19.2 & 10.0 \\
Lost confidence & 6.3 & 27.8 & 56.6 & 9.3 & 10.0 \\
Not worthy & 3.6 & 2.2 & 41.7 & 34.4 & 10.0 \\
Have reason to be happy & 1.0 & 7.3 & 26.5 & 65.2 & 10.0 \\
\hline
\end{tabular}

College students with high mental health are characterized by those who don't experience mental-emotional obstacles in various aspects of life. Table 2 shows that 65.2 percent of college students claimed that they always had a reason to be happy. Figure 4 shows the distribution of respondents based on reason in using social media. The reasons for using social media in this study are grouped into four groups of reasons for use, such as for entertainment, new information seeking, communication, and career or business. The majority of college students used social media to search for new information (42.4\%), considering that social media is an effective place to disseminate information at this time. In addition to information, 29.1 percent of college students use social networking, simple online journals (microblogs), and media sharing types to entertain themselves.

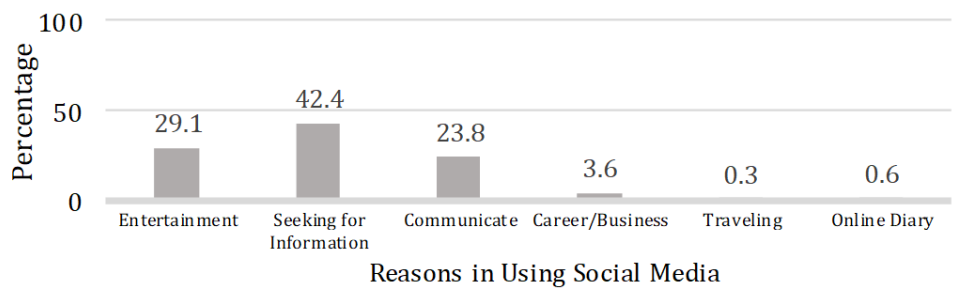

Figure 4.

Distribution of Respondents Based on Reason in Using Social Media. 
The results also showed that 3.6 percent of students use social media as a proponent of their career or business. In the research results, one of the students claimed to use social media to support her career as a model. In addition, two students claimed to use social media as an online diary (0.6\%) and one of the students claimed that social media was used for traveling reasons $(0.3 \%)$.

Social media abuse is an act of deviating from the use of social media in general. These actions are categorized as cyberbullying or harassing and insulting, deceiving or hiding identities, spreading hoax, and spreading pornographic content. The results found that only eight students used social media with the shortest duration of less than an hour a day (2.6\%). The biggest proportion of college students in the time duration of using social media in this study spent more than four hours a day (4.5\%) found in 124 students. In the majority, the level of abuse of social media in college students in this study was relatively low. The average value and standard deviation of social media abuse are 8.97 and 8.58 , respectively. Figure 5 presents the distribution of respondents based on social media abuse.

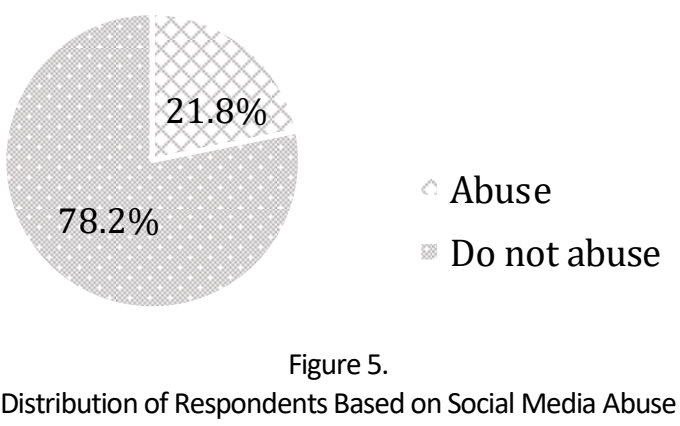

Table 3 shows that overall, the most common form of social media abuse is using a different account or a fake account with an average value of 18.71 . Two other categories of social media abuse that are quite often done are spreading hoax, also enjoying and spreading pornographic content with an average value of 11.70 and 7.01 respectively. 
Muhammad Defrianto, Alfiasari

Table 3.

Minimum and Maximum Score, Average Score, Standard Deviation

\begin{tabular}{lccc}
\hline Social media abuse category & Minimum & Maximum & Average \pm SD \\
\hline Fake or false account & 0.00 & 10.00 & $18.71 \pm 19.74$ \\
Harsh comment & 0.00 & 66.67 & $5.79 \pm 12.6$ \\
Insult comment & 0.00 & 66.67 & $3.04 \pm 9.65$ \\
Deploy hoax & 0.00 & 10.00 & $11.70 \pm 19.09$ \\
Enjoy and spread pornographic content & 0.00 & 83.33 & $7.01 \pm 12.13$ \\
Total of social media abuse & 0.00 & 44.44 & $8.97 \pm 8.58$ \\
\hline
\end{tabular}

Overall, the level of social media abuse is fairly low, but there are still college students who often even to abuse social media. This can be seen from the high maximum value in several categories such as the use of fake accounts, the spread of hoax, and the spread of pornographic content. After further investigation, students who frequently or even always abuse social media are students who use social media by two until more than four hours a day. Table 4 shows the majority of students claiming to never use a fake account to communicate with others on social media (66.6\%).

Table 4.

Distribution of Respondents Based on Social Media Abuse Indicator

\begin{tabular}{lccccc}
\hline Social media abuse indicator & Never & Rarely & Often & Always & Total \\
\hline Face account to hide the & 44.0 & 44.4 & 7.9 & 3.6 & 10.0 \\
identity & & & & & \\
Fake account to communicate & 66.6 & 26.8 & 5.6 & 1.0 & 10.0 \\
Give rude comment & 81.8 & 16.2 & 1.3 & 0.7 & 10.0 \\
Reply to comment harshly & 86.8 & 12.6 & 0.7 & 0.0 & 10.0 \\
Give insult comment & 91.4 & 7.6 & 1.0 & 0.0 & 10.0 \\
Reply to comment with insults & 92.1 & 7.3 & 0.7 & 0.0 & 10.0 \\
Spreading hoax & 69.2 & 27.2 & 3.0 & 0.7 & 10.0 \\
Enjoy pornography content & 68.5 & 26.5 & 4.3 & 0.7 & 10.0 \\
Spreading pornography & 96.4 & 2.6 & 0.7 & 0.3 & 10.0 \\
content & & & & & \\
\hline
\end{tabular}

Table 4 also shows that there is 3.6 percent of college students claiming to always use a fake account to hide their identity. As many as 5.6 percent and one percent of college students also seem to still often and always use fake social 
media accounts to communicate with others. College students who claimed to have used fake accounts on social media gave various reasons such as wanting to interact more widely with other people (6.95\%), interacting with special people $(13.57 \%)$, not wanting to be recognized $(13.90 \%)$ and just for fun (0.33\%). In general, college students never give rude comments $(81.8 \%)$ or reply to comments in the abusive language (86.8\%) of something or someone on social media. Students who frequently and always commented harshly in this study were respectively 1.3 percent and .7 percent. The reasons given by college students who have given or replied to comments in abusive language are because they are influenced by other people (4.96\%), accustomed to using abusive language $(1.65 \%)$, dislike someone or something $(4.96 \%)$, joking $(0.99 \%)$, emotions $(0.66 \%)$, comfortable $(0.33 \%)$, and approach form $(0.33 \%)$.

In addition, almost all college students also claimed to never give insulting comments (91.4\%) and reply comments with insults (92.1\%) on something or someone on social media. Only one percent and .7 percent of the college students admitted that they still often and always commented or replied with insults. College students who give or reply to comments with insults due to disliking someone or something (4.30\%), influenced by others $(2.64 \%)$, normally using words that are humiliating $(0.99 \%)$ and just joking $(0.33 \%)$. Some college students also claimed to have never spread hoax (69.2\%). Even so, there is still 3 percent of college students who claimed often spread hoax on social media. The spread of hoax by those who have done it is because they feel the information obtained is definitely correct $(9.27 \%)$, wants to be seen up to date $(7.94 \%)$, wants to share information $(1,65 \%)$, confirm the truth to the others $(1.32 \%)$, discussion material $(1.32 \%)$, just for fun $(0.66 \%)$, and for entertaining oneself $(0.33 \%)$. College students were also found to have never enjoyed pornographic content (68.5\%), and shared pornographic content (9.4\%) on social media. For those who have done it, this action is carried out because they want to share with friends (3.31\%) and only want to look for sensations $(0.33 \%)$.

The Chi-square test aims to measure the data correlation within a nominal and ordinal scale. This was chosen to be able to give a general description of the characteristics of students who are abusing and not abusing. Table 5 presents the results of the chi-square test on student characteristics, life satisfaction and mental health with social media abuse and the results show that there is gender and mental health is most significantly associated with social media abuse. 
Table 5.

Cross-Tabulation of Student Characteristics, Life Satisfaction, and Mental Health with Social Media Abuse and The Significance of The Chi-Square Test

\begin{tabular}{|c|c|c|c|}
\hline \multirow{2}{*}{ Variable } & \multicolumn{2}{|c|}{ Social media abuse } & \multirow{2}{*}{ Sig. } \\
\hline & Do not abuse & Abuse & \\
\hline \multicolumn{4}{|c|}{ College student characteristics } \\
\hline \multicolumn{4}{|c|}{ Gender } \\
\hline Male & $2.9 \%$ & $3.1 \%$ & \multirow[t]{2}{*}{$0.000^{* *}$} \\
\hline Female & $18.8 \%$ & $48 \%$ & \\
\hline \multicolumn{4}{|l|}{ Last education } \\
\hline Senior high school & $19.5 \%$ & $66.8 \%$ & \multirow{3}{*}{0.385} \\
\hline Vocational school & $0.9 \%$ & $7.6 \%$ & \\
\hline Islamic School & $1.3 \%$ & $3.6 \%$ & \\
\hline \multicolumn{4}{|l|}{ Total social media used } \\
\hline One type & $11.2 \%$ & $31.1 \%$ & \multirow[t]{2}{*}{0.089} \\
\hline More than one type & $1.5 \%$ & $47 \%$ & \\
\hline \multicolumn{4}{|l|}{ Frequency of use } \\
\hline Less than one hour & $0.6 \%$ & $1.9 \%$ & \multirow[t]{2}{*}{0.827} \\
\hline More than one hour & $21.1 \%$ & $76.1 \%$ & \\
\hline \multicolumn{4}{|l|}{ Life satisfaction } \\
\hline Less satisfied & $7.6 \%$ & $35.4 \%$ & \multirow{3}{*}{0.299} \\
\hline Quite satisfied & $1.9 \%$ & 31.7 & \\
\hline Satisfied & $3.3 \%$ & $1.9 \%$ & \\
\hline \multicolumn{4}{|l|}{ Mental health } \\
\hline Low & $3.9 \%$ & $24.5 \%$ & \multirow{3}{*}{$0.022 *$} \\
\hline Medium & $12.5 \%$ & $43.7 \%$ & \\
\hline High & $5.2 \%$ & $9.9 \%$ & \\
\hline
\end{tabular}

Note: *significance on $\mathrm{p}<0.05, * *$ significance on $\mathrm{p}<0.01$

In Table 6, the overall male student who abuses social media (3.1\%) is more than non-abusers (2.9\%). There are also more female students who abuse (48\%) than those who do not abuse (18.8\%). However, the difference in the number of female students is smaller than male students. Interesting things were found in this study where social media abuse is not only done by those who have low mental health (24.5\%), college students with medium mental health (43.7\%) and high (9.9\%) are still found at least have occasionally abused social media. Since social media abuse data specifically measures the frequency of acts of social media abuse processed by researchers as index data, this study also analyzes it further using the Pearson correlation test. Table 6 presents the results of the Pearson correlation test where mental health is also most 
significantly associated with social media abuse proven by the average value of social media abuse among female college students (6.76) which tends to be lower than male students (13.44). The results also found a significant negative relationship between mental health and social media abuse. This finding means that the better the mental health of students, the lower the level of college students' social media abuse.

Table 6.

Correlation Coefficient Values Between Student Characteristics, Life Satisfaction, and Mental Health with Social Media Abuse

\begin{tabular}{|c|c|c|c|}
\hline Variable & Life Satisfaction & Mental Health & $\begin{array}{c}\text { Social Media } \\
\text { Abuse }\end{array}$ \\
\hline \multicolumn{4}{|l|}{ College Student } \\
\hline \multicolumn{4}{|l|}{ Characteristic } \\
\hline Age (years old) & -0.085 & 0.032 & 0.058 \\
\hline Life Satisfaction & & 0.101 & -0.099 \\
\hline Mental Health & & & $-0.247 * *$ \\
\hline
\end{tabular}

Note: ${ }^{*}$ significance on $\mathrm{p}<.005,{ }^{* *}$ significance on $\mathrm{p}<0.01$

The results found a significant negative relationship between mental health and social media abuse were the better mental health, the lower the level of social media abuse. Correlation tests by treating social media abuse as nominal data and testing the relationship between research variables with the social media abuse index show consistent results. Mental health is associated with social media abuse.

Table 7.

Regression Result of Characteristic, Life Satisfaction, Mental Health towards Social Media Abuse

\begin{tabular}{lccc}
\hline \multirow{2}{*}{ Variable } & \multicolumn{3}{c}{ Social media abuse (0= Do not abuse, $1=$ Abuse) } \\
\cline { 2 - 4 } & $\mathrm{B}$ & $\operatorname{Exp}(\mathrm{B})$ & Sig. \\
\hline Constant & 1.758 & 5.800 & 0.565 \\
Age (years old) & 0.140 & 1.151 & 0.341 \\
Gender (0=Male, 1=Female) & -1.468 & 0.230 & $0.000^{* *}$ \\
Amount of social media used & 0.257 & 1.293 & 0.082 \\
Life satisfaction (index) & 0.001 & 1.001 & 0.927 \\
Mental health (index) & -0.039 & 0.961 & $0.001^{* *}$ \\
\hline \multicolumn{1}{c}{ Sig } & \multicolumn{3}{c}{$0.000^{* *}$} \\
Nagelkerke $R$ Square & \multicolumn{3}{c}{0.151} \\
\hline
\end{tabular}

Note: *significance on $\mathrm{p}<0.05,{ }^{* *}$ significance on $\mathrm{p}<0.01$ 
The logistic regression test indicates that the independent variables in this research such as gender have the most significant influence on social media abuse. The value of $B$ on the gender variable is $-1,468$ which means that female students tend to have lower intensity of social media abuse. This study's results can also be interpreted with another meaning where male students tend to abuse social media more than female students. Table 7 also shows the influence of mental health on social media abuse. This mental health variable which has a $B$ value of -0.039 explains that the higher or better the mental health of college students will influence the decreased tendency to abuse social media.

The results of the study produced a coefficient of determination (Nagelkerke R Square) of 0.151 or 15.1 percent. This explains that 15.1 percent of the independent variables used in the study can influence the social media abuse variable on students. This statement indicates that 84,9 percent social media abuse is influenced by other factors or other variables that not being analyzed in this study.

This study found that there was an influence of the gender of students on the abuse of social media. Another meaning of this is that men and women have different patterns in abusing social media. Previous studies have explained that male students are more likely to be abusers either directly or virtually. ${ }^{25}$ The same thing is also seen in the results of Deniz which stated that boys are equally involved in cyberbullying and more often affected by cyberbullying than girls. ${ }^{26}$ The phenomenon of gender differences in abuse behavior is also supported by the existence of a significant negative relationship between gender and social media abuse. The proportion of male students who abuse social media is more than male students who don't abuse. The average value of male students' social media abuse that is higher than female students also supports the differences in social media abuse by gender. This confirms that male students tend to abuse social media more often than female students. The results of Saripah and Pratita ${ }^{27}$ and Wiryada et al..$^{28}$ also stated that male students had the intensity of

\footnotetext{
25Peter Smith, Fran Thompson, and Saba Bhatti, "Ethnicity, Gender, Bullying and Cyberbullying in English Secondary School Pupils," Studia Edukacyjne 23 (2012): 7-18.

${ }^{26}$ Metin Deniz, "Istraživanje Virtualnog Zlostavljanja Učenika Osnovne Škole s Pozicija Zlostavljača i Žrtve u Odnosu Na Spol, Razred i Socioekonomski Status," Croatian Journal of Education 17, no. 3 (2015): 659-80, https://doi.org/10.15516/cje.v17i3.835.

27Ipah Saripah and Ajeng Nurul Pratita, "Kecenderungan Perilaku Cyberbullying Peserta Didik Berdasarkan Jenis Kelamin," Pedagogia 16, no. 3 (2018): 180, https://doi.org/10.17509/ pdgia.v16i3.13553.
} 
harassment actions on social media slightly higher than female students. Overall, the level of social media abuse is fairly low but there are still students who often even take actions to abuse social media. Interesting things were found in this study. If it is seen by gender, there are differences between male and female students in the frequency of each act of abuse. Male students were found more often to comment in abusive or offensive language while female students were found to use fake or different accounts more often and spread uncertain news or hoaxes.

Furthermore, the results of the study showed that mental health influences on social media abuse. Previous research has proven that social media does have an influence and relationship on one's mental health. Excessive use of social media is believed to increase symptoms of depression and loneliness ${ }^{29}$ and have a negative impact on one's mental health. ${ }^{30}$ This research succeeded in proving the opposite direction in which the mental health of students also influenced social media abuse behavior. The significant negative relationship between mental health and social media abuse also confirmed that improving mental health of students will cause a decrease in students' tendency to abuse social media. Low mental health indicates a person's emotional problems. ${ }^{31}$

Natalia in her research also explained that adolescents who are mentally vulnerable are likely to become cyberbullying perpetrators. ${ }^{32}$ Individuals with good mental health will not abuse social media because mentally healthy individuals can undergo a social relationship well, behave and behave prosocially, avoid criminal acts ${ }^{33}$ and have values of goodness, truth and piety. ${ }^{34}$

${ }^{28}$ Okik Adishya Banu Wiryada, Nuke Martiarini, and Tri Esti Budiningsih, "Gambaran Cyberbullying pada Remaja Pengguna Jejaring Sosial di SMA Negeri 1 dan SMA Negeri 2 Ungaran," Intuisi: Jurnal Psikologi Ilmiah 9, no. 1 (2017): 86-92, https://doi.org/10.15294/intuisi.v9i1.9577.

${ }^{29}$ Igor Pantic, "Online Social Networking and Mental Health," Cyberpsychology, Behavior and Social Networking 17, no. 10 (2014): 652-57, https://doi.org/10.1089/cyber.2014.0070.

${ }^{30}$ Sujarwoto Sujarwoto, Gindo Tampubolon, and Adi Cilik Pierewan, "A Tool to Help or Harm? Online Social Media Use and Adult Mental Health in Indonesia," International Journal of Mental Health and Addiction 17, no. 4 (2019): 1076-93, https://doi.org/10.1007/s11469-019-00069-2.

${ }^{31}$ Atsushi Nishida, Marcus Richards, and Mai Stafford, "Prospective Associations between Adolescent Mental Health Problems and Positive Mental Wellbeing in Early Old Age," Child and Adolescent Psychiatry and Mental Health 10, no. 1 (2016): 12, https://doi.org/10.1186/s13034-0160099-2.

${ }^{32}$ Natalia, "Remaja, Media Sosial dan Cyberbullying."

${ }^{33}$ N. Kreitman, "Mental Health for All?," BMJ: British Medical Journal 299, no. 6711 (1989): 1292-93, https://doi.org/10.1136/bmj.299.6711.1292. 
The college students who abuse social media in this study admitted that they generally committed social media abuse for various reasons such as because of the influence of others, dislike feeling, habits, jokes, and personal reasons. In many cases, perpetrators of social media abuse such as harassment often suffer mental health problems. ${ }^{35}$ Even so, most of the social media abuse rates of college students in this study were still relatively low because the students had quite good mental health. College students in this study claimed to be able to concentrate well, deal with problems, always have a reason to be happy, and enjoy their activities well. However, not a few who felt living under pressure, unable to overcome problems, lose confidence, worthless, and unhappy or depressed. Students would indeed experience more mental health problems when in college than the level of education that previously pursued. ${ }^{36}$ Academic pressure can be a factor in the emergence of mental health in higher education. ${ }^{37}$ Although the majority of college students' mental health is said to be quite good, there are still college students who have low mental health in a number that is not small. This is certainly interesting considering the level of student social media abuse as a whole is categorized as low. This finding indicates the possibility that students will not abuse social media despite their low mental health. This phenomenon can occur if students with low mental health use social media positively. Some teenagers who are feeling depressed could just use social media to improve mood, seek social support, vent emotions, look for social groups related to conditions, or even just to mere diversion or entertainment. ${ }^{38}$ Individuals who express mental health problems on social media tend to get social support from others so that abuse can be avoided. 39

\footnotetext{
${ }^{34}$ Siswanto, Kesehatan Mental: Konsep, Cakupan, dan Perkembangannya.

${ }^{35}$ Chinwon Rim and David Y. Son, "Hyperbranched Poly(Carbosilanes) from Silyl-Substituted Furans and Thiophenes," Macromolecules 36, no. 15 (2003): 5580-84, https://doi.org/ 10.1021/ma026022i.

36 Melissa Wood, “The State of Mental Health on College Campuses," Inquiry: The Journal of the Virginia Community Colleges 17, no. 1(2012): 5-15.

${ }^{37}$ Paola Pedrelli et al., "Buku Panduan Program Ijazah Dasar Sesi Akademik 2013/2014," Acad Psychiatry39, no. 5 (2015): 503-11, https://doi.org/10.1007/s40596-014-0205-9.College.

${ }^{38}$ Ana Radovic et al., "Depressed Adolescents' Positive and Negative Use of Social Media," Journal of Adolescence 55, no. 1 (February 2017): 5-15, https://doi.org/10.1016/j.adolescence. 2016.12.002.

${ }^{39}$ John A Naslund et al., "Naturally Occurring Peer Support through Social Media: The Experiences of Individuals with Severe Mental Illness Using YouTube," ed. Lieuwe De Haan, PLoS ONE 9, no. 10 (2014): e110171, https://doi.org/10.1371/journal.pone.0110171.
} 
In addition, the results of the study indicate that life satisfaction is not related and affects mental health and social media abuse. This result is not in line with the statement that positive mental health mostly comes from the perspective of life satisfaction. ${ }^{40}$ This finding is also not in line with the statement that there is a strong and reciprocal association between mental health and life satisfaction. ${ }^{41}$ Life satisfaction depends on how well an individual evaluates his life objectively by assessing a more positive domain. ${ }^{42}$ Life satisfaction of first-year students at IPB is quite satisfied. ${ }^{43}$ The life satisfaction of IPB college students in this study as a whole is in the less satisfied category. The majority of college students are most satisfied with the happiness they have now. College students are satisfied with their happiness because students are also found to be satisfied with friends and their current social environment. Ardiansyah, ${ }^{44}$ Raharjo and Sumargi ${ }^{45}$ proved a significant relationship between social peer support and one's happiness. Meanwhile, most students are less satisfied with their free time at the moment.

The limitation of this study is that the measurement of student life satisfaction and mental health is done in a quite simple way. This is due to the fact that data retrieval is done virtually so that the questionnaire that is too complex is concerned to be able to disrupt the focus of the respondents when filling out the questionnaire. Other than that, both life satisfaction and mental health variables are only measured by the dimensions represented by one to two statements. In addition, this study only measured social media abuse in general. The distribution of data in this study was also abnormal, so the regression test between variables used logistic regression test. Data is not normally distributed due to extreme values and lack of discrimination data so that overall data tends to be homogeneous.

${ }^{40} \mathrm{WHO}$, Investing in Mental Health: Evidence for Action.

${ }^{41}$ D. M. Fergusson et al., "Life Satisfaction and Mental Health Problems (18 to 35 Years)," Psychological Medicine 45, no. 11 (2015): 2427-36, https://doi.org/10.1017/S0033291715000422.

${ }^{42}$ R.W Linsiya, "Perbedaan Kepuasan Hidup Antara Mahasiswa Strata 1 (S1) dan Strata 2 (S2)," Psycology Forum UMM 1, no. 7 (2015): 284-87.

${ }^{43}$ Dyanza Sri Novianti and Alfiasari Alfiasari, "Kepuasan Hidup Mahasiswa Tingkat Pertama: Kaitannya dengan Karakter Mahasiswa dan Gaya Pengasuhan Orang Tua," Jurnal Ilmu Keluarga dan Konsumen 10, no. 1 (2017): 13-23, https://doi.org/10.24156/jikk.2017.10.1.13.

${ }^{44}$ Atrof Ardiansyah, "Hubungan Antara Dukungan Sosial Teman Sebaya dengan Kebahagiaan Pada Mahasiswa" (Universitas Islam Negeri Sultan Sarif Kasim Riau, 2014).

45Yosua Ong Raharjo and Agnes Maria Sumargi, "Dukungan Sosial dan Kepuasan Hidup pada Mahasiswa Universitas Katolik Widya Mandala Surabaya yang Berasal dari Luar Jawa," Experienta: Jurnal Psikologi Indonesia 6, no. 1 (2018): 1-10, https://doi.org/10.33508/exp.v6i1.1785. 


\section{Conclusion}

College students involved in this study were 19 years old on average with the majority of their last educational background is high school. The majority of college students use one type of social media with an average duration of use of three to more than four hours. The majority of college students' life satisfaction is in the unsatisfied category while the majority of college students' mental health is in the medium category. Social media abuse by college students are in the low category with the most common form of abuse are the use of different or fake accounts and the spread of hoax. College student use social media to find new information, entertain themselves, and communicate with others.

The amount of social media used and its frequency were found to be unrelated to social media abuse. Male students involved in this study were found to have the higher intensity to abuse social media than female students. In this study, life satisfaction was found to be unrelated and had no effect on mental health and social media abuse. Meanwhile, mental health is proven to be negatively related and most significantly associated with abuse behavior, where an increase in mental health will decrease the tendency of social media abuse among college students. Mental health was also emphasized as having a significant effect on social media abuse. In addition, further research is suggested to be able to measure life satisfaction and mental health deeper and be able to analyze the other factors such as family factors and the environment that may lead to abuse behavior.[s]

\section{References}

Agusti, Riska Dwi Cahyani Wahyu, and Tino Leonardi. "Hubungan Antara Kesepian dengan Problematic Internet Use pada Mahasiswa." Jurnal Psikologi Klinis dan Kesehatan Mental 4, no. 1 (2015): 9-13.

Ardiansyah, Atrof. "Hubungan antara Dukungan Sosial Teman Sebaya dengan Kebahagiaan pada Mahasiswa." Universitas Islam Negeri Sultan Sarif Kasim Riau, 2014.

Chukwudi, John Henry, and Egbeyemi Taiwo. "Use and Abuse of Social Networking Websites (Facebook) among Undergraduate Students in Tai Solarin University of Education." In Proceedings of the 2nd Interdisciplinary Conference of TASUED-UCC 2016, Tai Solarin University of Education, Nigeria, 2016. 
Deniz, Metin. "Istraživanje Virtualnog Zlostavljanja Učenika Osnovne Škole s Pozicija Zlostavljača i Žrtve u Odnosu Na Spol, Razred i Socioekonomski Status." Croatian Journal of Education 17, no. 3 (2015): 659-80. https://doi.org/10.15516/ cje.v17i3.835.

Fergusson, D. M., G. F.H. McLeod, L. J. Horwood, N. R. Swain, S. Chapple, and R. Poulton. "Life Satisfaction and Mental Health Problems (18 to 35 Years)." Psychological Medicine 45, no. 11 (2015): 2427-36. https://doi.org/10.1017/ S0033291715000422.

Fisher, Eddie John. "From Cyber Bullying to Cyber Coping: The Misuse of Mobile Technology and Social Media and Their Effects on People's Lives." Business and Economic Research 3, no. 2 (2013): 127-45. https://doi.org/10.5296/ ber.v3i2.4176.

Frith, Emily. "Social Media and Children's Mental Health: A Review of the Evidence." The Education Policy Institute, 2017, 1-29.

Glazzard, Jonathan, and Samuel Stones. "Social Media and Young People's Mental Health." In Technology and Child Mental Health, 32. London: IntechOpen, 2009. https://doi.org/10.5772/intechopen.88569.

Goldberg, D., and P. Williams. A User's Guide to the General Health Questionnaire. Windsor: NFER, 1998.

Grigg, Margaret, and Shekhar Saxena. "Promoting Mental Health Nursing Research in Low and Middle Income Countries." International Nursing Review 51, no. 4 (2004): 194-95. https://doi.org/10.1111/j.1466-7657.2004.00268.x.

Hadjam, M., and Wahyu Widhiarso. "Pengujian Model Peranan Kecakapan Hidup terhadap Kesehatan Mental." Jurnal Psikologi UGM 38, no. 1 (2011): 61-72. https://doi.org/10.22146/jpsi.7665.

Hidayat, Dede Rahmat. Bimbingan Konseling: Kesehatan Mental di Sekolah. Bandung: Remaja Rosdakarya, 2013.

Kreitman, N. “Mental Health for All?” BMJ: British Medical Journal 299, no. 6711 (1989): 1292-93. https://doi.org/10.1136/bmj.299.6711.1292.

Li, Dongping, Wenhua Zhang, Xian Li, Yueyue Zhou, Liyan Zhao, and Yanhui Wang. "Stressful Life Events and Adolescent Internet Addiction: The Mediating Role of Psychological Needs Satisfaction and the Moderating Role of Coping Style." Computers in Human Behavior 63 (2016): 408-15. https://doi.org/10.1016/ j.chb.2016.05.070.

Linsiya, R.W. "Perbedaan Kepuasan Hidup antara Mahasiswa Strata 1 (S1) dan Strata 2 (S2)." Psycology Forum UMM 1, no. 7 (2015): 284-87. 
Longstreet, Phil, and Stoney Brooks. "Life Satisfaction: A Key to Managing Internet \& Social Media Addiction." Technology in Society 50 (2017): 73-77. https://doi.org/ 10.1016/j.techsoc.2017.05.003.

Lounsbury, John W., Richard A. Saudargas, Lucy W. Gibson, and Frederick T. Leong. “An Investigation of Broad and Narrow Personality Traits in Relation to General and Domain-Specific Life Satisfaction of College Students." Research in Higher Education 46, no. 6 (2005): 707-29. https://doi.org/10.1007/s11162-004-41406.

Naslund, John A., Stuart W. Grande, Kelly A. Aschbrenner, and Glyn Elwyn. "Naturally Occurring Peer Support through Social Media: The Experiences of Individuals with Severe Mental Illness Using YouTube." Edited by Lieuwe De Haan. PLoS ONE 9, no. 10 (2014): e110171. https://doi.org/10.1371/journal.pone.0110171.

Nasrullah, Rulli. Media Sosial Perspektif Komunikasi, Budaya, dan Sosioteknologi. Bandung: Simbiosa Rekatama Media, 2015.

Natalia, El Chris. "Remaja, Media Sosial dan Cyberbullying." Jurnal Ilmiah Komunikasi 5, no. 2 (2016): 119-37. https://doi.org/10.33508/jk.v5i2.991.

Nayana, Firra Noor. "Kefungsian Keluarga dan Subjective Well-Being pada Remaja." Jurnal Ilmiah Psikologi Terapan 1, no. 230-244 (2013). https://doi.org/ 10.22219/jipt.v1i2.1580.

Nishida, Atsushi, Marcus Richards, and Mai Stafford. "Prospective Associations between Adolescent Mental Health Problems and Positive Mental Wellbeing in Early Old Age." Child and Adolescent Psychiatry and Mental Health 10, no. 1 (2016): 12. https://doi.org/10.1186/s13034-016-0099-2.

Novianti, Dyanza Sri, and Alfiasari Alfiasari. "Kepuasan Hidup Mahasiswa Tingkat Pertama: Kaitannya dengan Karakter Mahasiswa dan Gaya Pengasuhan Orang Tua." Jurnal Ilmu Keluarga dan Konsumen 10, no. 1 (2017): 13-23. https://doi.org/10.24156/jikk.2017.10.1.13.

Pandie, Mira Marleni, and Ivan Th. J. Weismann. "Pengaruh Cyberbullying di Media Sosial terhadap Perilaku Reaktif sebagai Pelaku Maupun sebagai Korban Cyberbullying pada Siswa Kristen SMP Nasional Makassar." Jurnal Jaffray 14, no. 1 (2016): 43-62. https://doi.org/10.25278/jj.v14i1.188.43-62.

Pantic, Igor. "Online Social Networking and Mental Health." Cyberpsychology, Behavior and Social Networking 17, no. 10 (2014): 652-57. https://doi.org/10.1089/ cyber.2014.0070.

Pedrelli, Paola, Maren Nyer, Albert Yeung, Courtney Zulauf, and Timothy Wilens. "Buku Panduan Program Ijazah Dasar Sesi Akademik 2013/2014." Acad Psychiatry 39, no. 5 (2015): 503-11. https://doi.org/10.1007/s40596-014-0205-9.College. 
Puvill, Thomas, Jolanda Lindenberg, Antonius J. M. De Craen, Joris P.J. Slaets, and Rudi G.J. Westendorp. "Impact of Physical and Mental Health on Life Satisfaction in Old Age: A Population Based Observational Study." BMC Geriatrics 16, no. 1 (2016): 19. https://doi.org/10.1186/s12877-016-0365-4.

Radovic, Ana, Theresa Gmelin, Bradley D. Stein, and Elizabeth Miller. "Depressed Adolescents' Positive and Negative Use of Social Media." Journal of Adolescence 55, no. 1 (2017): 5-15. https://doi.org/10.1016/j.adolescence.2016.12.002.

Raharjo, Yosua Ong, and Agnes Maria Sumargi. “Dukungan Sosial dan Kepuasan Hidup pada Mahasiswa Universitas Katolik Widya Mandala Surabaya yang Berasal dari Luar Jawa." Experienta: Jurnal Psikologi Indonesia 6, no. 1 (2018): 1-10. https://doi.org/10.33508/exp.v6i1.1785.

Rim, Chinwon, and David Y. Son. "Hyperbranched Poly(Carbosilanes) from SilylSubstituted Furans and Thiophenes." Macromolecules 36, no. 15 (2003): 558084. https://doi.org/10.1021/ma026022i.

Sanjaya, Ridwan. Menyiasati Tren Digital pada Anak dan Remaja. Jakarta: Elex Media Komputindo, 2011.

Saripah, Ipah, and Ajeng Nurul Pratita. "Kecenderungan Perilaku Cyberbullying Peserta Didik Berdasarkan Jenis Kelamin.” Pedagogia 16, no. 3 (2018): 180. https://doi.org/10.17509/pdgia.v16i3.13553.

Siswanto, Siswanto. Kesehatan Mental: Konsep, Cakupan, dan Perkembangannya. Yogyakarta: Andi Offset, 2007.

Smith, Peter, Fran Thompson, and Saba Bhatti. "Ethnicity, Gender, Bullying and Cyberbullying in English Secondary School Pupils." Studia Edukacyjne 23 (2012): 7-18.

Sujarwoto, Sujarwoto, Gindo Tampubolon, and Adi Cilik Pierewan. "A Tool to Help or Harm? Online Social Media Use and Adult Mental Health in Indonesia." International Journal of Mental Health and Addiction 17, no. 4 (2019): 1076-93. https://doi.org/10.1007/s11469-019-00069-2.

West, Nalini Maria. "The Relationship among Personality Traits, Character Strengths, and Life Satisfaction in College Students." Dissertation Abstracts International: Section B: The Sciences and Engineering 67, no. 10-B (2007): 6107.

_-_ . "The Relationship Among Personality Traits, Character Strengths, and Life Satisfaction in College Students." University of Tennessee, Knoxville, 2006.

WHO. Investing in Mental Health: Evidence for Action. Geneva, Switzerland: World Health Organization, 2003.

Wiryada, Okik Adishya Banu, Nuke Martiarini, and Tri Esti Budiningsih. "Gambaran Cyberbullying pada Remaja Pengguna Jejaring Sosial di SMA Negeri 1 dan SMA 
Muhammad Defrianto, Alfiasari

Negeri 2 Ungaran." Intuisi: Jurnal Psikologi Ilmiah 9, no. 1 (2017): 86-92. https://doi.org/10.15294/intuisi.v9i1.9577.

Wood, Melissa. "The State of Mental Health on College Campuses." Inquiry: The Journal of the Virginia Community Colleges 17, no. 1 (2012): 5-15.

Zulaiha, Siti, Sagiman Sagiman, and Mutia Mutia. "Edukasi Literasi Informasi bagi Anak dan Remaja untuk Meminimalisir Penyalahgunaan Media Jejaring Sosial." Jurnal Harkat: Media Komunikasi Gender 15, no. 2 (November 27, 2019): 116-25. https://doi.org/10.15408/harkat.v15i2.13469. 